\title{
The Enigma of Howard Gardner's Multiple Intelligences Theory in the Area of Organizational Effectiveness
}

\author{
Narges Sariolghalam \\ Applied Mathematics, Faculty of Mathematics \\ Payam e Noor University of Maragheh, Iran \\ Tel: 98-421-2275121 E-mail: n_ghalam@yahoo.com \\ Mohammad Reza Noruzi (Corresponding author) \\ Executive Master Business Administration, EMBA \\ Islamic Azad University, Kaleibar, Iran \\ Faculty of Humanity Sciences, Department of Management and Accounting \\ Young Researchers Club Member, IAU Bonab, Iran \\ Tel: 98-426-4224915Ｅ-mail: mr.noruzi.pnu@gmail.com \\ Gholam Reza Rahimi \\ Public Management, $\mathrm{Ph}$. D \\ Islamic Azad University, Kaleibar, Iran \\ Faculty of Humanity Sciences, Department of Management and Accounting
}

Tel: 98- 426-4224915

\begin{abstract}
Most organizational theorists agree that having intelligent managers is one of the most important contributors to overall organizational success and task or mission cannot be accomplished by not paying attention to manager's intelligence.

This research is a sole study about the role of Multiple Intelligences, (MI) in organizational effectiveness, (OE) in management era. Nowadays managers should be more intelligent than their rivals in this competitive and turbulent market. This paper aims to explore the MI notion in details. Also the relationship of MI and OE comes as well.
\end{abstract}

Keywords: Organizational effectiveness, Multiple intelligences, Management, Organization

\section{Introduction}

What is it about bosses that influence their relationship with employees? What skills do bosses need to prevent employees from leaving? The most effective bosses are those who have the ability to sense how their employees feel about their work situation and to intervene effectively when those employees begin to feel discouraged or dissatisfied. Effective bosses are also able to manage their own emotions, with the result that employees trust them and feel good about working with them. In short, bosses whose employees stay are bosses who manage with multiple intelligences (Cherniss, 2001).

The work of Howard Gardner sparked a shift in our traditional thinking by suggesting that one's multiple intelligences are as important as one's ability to reason. This paper extended this idea to OE practice and organizations.

Effectiveness is an elusive concept that can be approached through several models, none of which inappropriate in all circumstances.

This paper aims to synthesize ground-breaking research in management and psychology that highlights the importance of relational competence in the work place. Building on emerging research and best practices, this highly experiential examines the history and role of multiple intelligences in various work settings. 


\section{Background of Multiple Intelligences}

There are different approaches to understanding intelligence. The psychometric view is the most traditional one. According to this approach, there is a single intelligence, which is often called general intelligence. Every individual is born with a certain intelligence or potential intelligence, which is difficult to be changed. Psychologists can assess one's intelligence (IQ) by means of short-answer tests and other purer measures such as the time it takes to react to a flashing light or the presence of a certain pattern of brain waves (Gardner, 2004). But the traditional IQ tests did not satisfy the researchers, so they developed a number of alternative theories, all of which suggest that intelligence is the result of a number of independent abilities that uniquely contribute to human performance. These theories suggest that rather than being fixed, unitary, and predetermined, intelligence is modifiable, multi-faceted, and capable of development (Gardner, 1993; Sternberg, 1986; Vygotsky, 1978; Yekovich, 1994; cited in Campbell, 2000, p. 8). Some of these theories have been summarized in the following paragraphs:

Robert Sternberg in his view of intelligence proposed three types of intelligence: 1) Componential Intelligence (analytical thinking): academic abilities to compare, evaluate and solve problems. 2) Experiential Intelligence (creativity and insight): the ability to invent, discover and theorize. 3) Practical Intelligence (street smarts): contextual abilities to adapt to the environment (Brown, 2000; Chastain, 1988). This theory of intelligence claims that intelligent behavior stems from a balance between analytical, creative and practical abilities and that these abilities function collectively to allow individuals to achieve success within particular socio-cultural contexts (Sternberg, 1988).

Gardner, in his MI theory, proposes that human intelligence has multiple dimensions that must be acknowledged and developed in education. He notes that traditional IQ or intelligence tests (such as Stanford-Binet test) measure only logic and language, but there are other equally important types of intelligence (Richrads \& Rodgers, 2001).

According to Gardner (1993), intelligence is a biopsychological potential. Intelligences cannot be seen or counted. They are used to process information and can be activated in a cultural setting to solve problems or create products that are of value in a culture. These potentials' activation depends upon the values of a particular culture, the opportunities available in that culture, and the personal decisions made by individuals and/or their families, schoolmasters, and others.

\section{Multiple Intelligences Theory}

Gardner's MI theory posits that human beings possess at least eight intelligences, to a greater or lesser extent. They are as follow (Armstrong, 2009, pp.6-7):

Once this broader and more pragmatic perspective was taken, the concept of intelligence began to lose its mystique and became a functional concept that could be seen working in people's lives in a variety of ways. Gardner provided a means of mapping the broad range of abilities that humans possess by grouping their capabilities into the following eight comprehensive categories or "intelligences":

Linguistic: The capacity to use words effectively, whether orally (e.g., as a storyteller, orator, or politician) or in writing (e.g., as a poet, playwright, editor, or journalist). This intelligence includes the ability to manipulate the syntax or structure of language, the phonology or sounds of language, the semantics or meanings of language, and the pragmatic dimensions or practical uses of language. Some of these uses include rhetoric (using language to convince others to take a specific course of action), mnemonics (using language to remember information), explanation (using language to inform), and metalanguage (using language to talk about itself).

Logical-mathematical: The capacity to use numbers effectively (e.g., as a mathematician, tax accountant, or statistician) and to reason well (e.g., as a scientist, computer programmer, or logician). This intelligence includes sensitivity to logical patterns and relationships, statements and propositions (if-then, cause-effect), functions, and other related abstractions. The kinds of processes used in the service of logical-mathematical intelligence include categorization, classification, inference, generalization, calculation, and hypothesis testing.

Spatial: The ability to perceive the visual-spatial world accurately (e.g., as a hunter, scout, or guide) and to perform transformations upon those perceptions (e.g., as an interior decorator, architect, artist, or inventor). This intelligence involves sensitivity to color, line, shape, form, space, and the relationships that exist between these elements. It includes the capacity to visualize, to graphically represent visual or spatial ideas, and to orient oneself appropriately in a spatial matrix.

Bodily-kinesthetic: Expertise in using one's whole body to express ideas and feelings (e.g., as an actor, a mime, an athlete, or a dancer) and facility in using one's hands to produce or transform things (e.g., as a craftsperson, 
sculptor, mechanic, or surgeon). This intelligence includes specific physical skills such as coordination, balance, dexterity, strength, flexibility, and speed, as well as proprioceptive, tactile, and haptic capacities.

Musical: The capacity to perceive (e.g., as a music aficionado), discriminate (e.g., as a music critic), transform (e.g., as a composer), and express (e.g., as a performer) musical forms. This intelligence includes sensitivity to the rhythm, pitch or melody, and timbre or tone color of a musical piece. One can have a figural or "top-down" understanding of music (global, intuitive), a formal or "bottom-up" understanding (analytic, technical), or both.

Interpersonal: The ability to perceive and make distinctions in the moods, intentions, motivations, and feelings of other people. This can include sensitivity to facial expressions, voice, and gestures; the capacity for discriminating among many different kinds of interpersonal cues; and the ability to respond effectively to those cues in some pragmatic way (e.g., to influence a group of people to follow a certain line of action).

Intrapersonal: Self-knowledge and the ability to act adaptively on the basis of that knowledge. This intelligence includes having an accurate picture of oneself (one's strengths and limitations); awareness of inner moods, intentions, motivations, temperaments, and desires; and the capacity for self-discipline, self-understanding, and self-esteem.

Naturalist: Expertise in the recognition and classification of the numerous species — the flora and fauna —of an individual's environment. This also includes sensitivity to other natural phenomena (e.g., cloud formations, mountains, etc.) and, in the case of those growing up in an urban environment, the capacity to discriminate among inanimate objects such as cars, sneakers, and CD covers.

Daniel Golman introduced the concept of Emotional Intelligence (EI). He claimed that efficient mental or cognitive processing is necessary for controlling even a handful of core emotions- anger, fear, enjoyment, love, disgust, and others. More to the point, Golaman compared the rational mind with the emotional mind. In comparing the rational mind with the emotional mind, Golman argued that the emotional mind is far quicker and acts without even pausing to consider what it is doing. He stated that the quickness of emotional mind prevents a deliberate, analytic reflection that is the sign of the thinking mind (Golman, 1995).

The theoretical framework of the present study is based on Gardner's MI theory. This theory has a positive and expansive view towards intelligence (Campbell, 2000).

\section{Organizational Effectiveness}

Peter Drucker (1990) observed that the nonprofit institution in America is in many ways a "growth industry." Accompanying this expansion has been a growing body of literature prescribing methods for increasing the effectiveness of nonprofit organizations, their managers, and their boards. But research on these matters remains sparse (Penn, 1991; Powell, 1987; Green \& Griesingev, 1996).

According to Drucker (1974, p. 4 3, "Efficiency is concerned with doing things right. Effectiveness is doing the right things." Whereas this definition of effectiveness is often cited, there is a lack of consensus about how to operationalize the concept (for example, Anspach, 1991; Cameron and Whetten, 1983; Cook and Brown, 1990; Hall, 1991; Herman, 1990; Kanter and Brinkerhoff, 1981; Kraft, 1991; Quinn and Rohrbaugh, 1983; Seashore, 1983; Seashore and Yuchtman, 1967; Spray, 1976; Steers, 1977). If effectiveness is doing the right things, then who determines what is right, what constitutes the right things, and how they are to be measured? The literature on organizational effectiveness contains a variety of competing perspectives. Indeed, the very concept of effectiveness has been challenged on the grounds that multiple constituencies often cannot agree on the factors or weights underlying such evaluative judgments (Green \& Griesingev, 1996).

\section{Major Approaches in Assessing Organizational Effectiveness}

Despite all obstacles to a consensual definition of organizational effectiveness and to a consistent procedure for assessing the concept not all assessment of organizational effectiveness have been done in a completely random fashion. Four different approaches or models have been used by evaluators to define and assesses organizational effectiveness (see Table 1). The first and the most widely used is approach which links effectiveness to the accomplishment of organizational goal and called Goal model (Price, 1972sws). The second approach for the effectiveness is called the system- resource approach. In this view organizations are not assumed to posses goals, nor is goal accomplishment a relevant consideration. Rather organizations are effective insofar as they acquire needed resources for system maintenance (Yutchman and Seashore, 1967).

A third approach to effectiveness focuses on the internal processes and operations of the organizations and for these organizations effective organizations are those with an absence of internal strain and called "Internal 
Process Model" (Likert, 1967). Te forth approach called strategic constituencies approach and focuses on the extent to which the organization's strategic constituencies are at least minimally satisfied (Baugher, 1981).

Source: D. Baugher (Ed.). New Directionsfor Program Evaluation: Measuring Effectiveness, no. 11 San Francisco: Jossey-Bass, September 1981

There may be some circumstances in which any Effectiveness is an elusive concept that can be approached through several models, none of which inappropriate in all circumstances or for all organizations.

\section{Theory at the Policymaking Level}

There have been a number of cases in which MI theory has been incorporated at the highest levels of a nation's or international body's policymaking institutions. According to Gardner (2006a), “. . . I have been amazed to learn of jurisdictions in which the terminology of MI has been incorporated into white papers, recommendations by ministries, and even legislation. . . . Ihave heard from reliable sources that MI approaches are part of the policy landscape in such diverse lands as Australia, Bangladesh, Canada, China, Denmark, Ireland and the Netherlands" (p. 248). In Bangladesh, for example, with support from UNICEF, the government initiated its Intensive District Approach for All Learners project in the 1990s. As part of this effort, tens of thousands of teachers were trained in MI theory through the initiative Multiple Ways of Teaching and Learning. India's National Curriculum Framework for School Education requires teachers to be familiar with the concepts of multiple intelligences (Sarangapani, 2000). In Geneva, Switzerland, the prestigious International Baccalaureate (IB) Organization, which offers programs to over 600,000 students in 128 countries, has recently acknowledged Gardner's role in influencing its own approach to learning and managing the organizations: "Howard Gardner has been influential in changing views about learning and the ways we learn. Access and equity within the IB today is much wider than it was previously. It is acknowledged that all participants have strengths and weaknesses which must be supported in a strategic way for them to meet their potential (Reed, 2007; Armatrong, 2010m pp. 199-200).

\section{Multiple Intelligence and Organizational Effectiveness}

The underlying goal of most research on organizations is to improve their effectiveness. It is ironic, therefore, that no concrete definition of organizational effectiveness has yet emerged and that there is general lack of agreement as to the proper approach for assessing effectiveness (Cameron, 1978; Goodman and Pennings, 1977; Steers, 1977). Debates about which definition is best continue in the literature (Molnar and Rogers, 1976; Price, 1972), and some writers have become so discouraged with the ambiguity of the concept of organizational effectiveness that they suggest dropping it from the academic vernacular altogether (Goodman, 1979; Hannan and Freeman, 1977; D. Baugher 1981).

The strong performers reflect the benefits of affirmative, engaged design followed by participant commitment to structure design and implementation. To their participants, the structure had purpose and was more than a context for involvement; it elicited from volunteers and staff a high degree of commitment. This was true in organizations that differed substantially in their program objectives, resource environments, product and market activities, and organizational forms. Although the other high-ranking performers are not discussed in as much detail here, those that ranked high in one or both of the effectiveness scales shared a high level of engagement by organization members in decision making, and an open willingness among managers to create structures that made such engagement possible. The match of participant interest with a structural form that participants believed would facilitate their involvement was a common characteristic of the better performers (Kushner \& Poole, 1996).

Managers who have a good multiple intelligences can understand the challenges face with employees. Some challenges are shown below (Cherniss, 2001):

- $\quad$ People need to cope with massive, rapid change.

- People need to be more creative in order to drive innovation.

- People need to manage huge amounts of information.

- The organization needs to increase customer loyalty.

- $\quad$ People need to be more motivated and committed.

- $\quad$ People need to work together better.

- The organization needs to make better use of the special talents available in a diverse workforce.

- $\quad$ The organization needs to identify potential leaders in its ranks and prepare them to move up. 
- The organization needs to identify and recruit top talent.

- The organization needs to make good decisions about new markets, products, and strategic alliances.

- The organization needs to prepare people for overseas assignments.

A manager with high in MI is the "executive" of organizational intelligence. These managers must establish and encourage norms, roles, and rules for efficient application to known tasks, but must also be sensitive and responsive to change by employing sensitivity, problem solving and decision making strategies that allow for adaptation.

\section{A useful metaphor for understanding Organizational Effectiveness}

Organizational and Management effectiveness flows from the construct of intelligence. Psychologists regard intelligence as the ability to function effectively in the world. Intelligent people are those who have a store of knowledge and skills gained from experience that allow them to manage efficiently the tasks of daily life. A crucial aspect of intelligence, however, concerns the fact that the world is a dynamic and changing environment and skills and knowledge gained from past experience may not be sufficient to meet a new challenge. Effective intelligence involves using existing learning systems and sensitivity to the environment to expand, elaborate, and enhance existing knowledge to analyze new situations and develop new solutions that help to routinize the environment again. Organizations must do the same things to be effective. They must have sound internal systems and data based on past experience, but must also be sensitive to changing environments and flexible enough to develop new systems and new knowledge to cope with change.

Manager is the "executive" of organizational intelligence. Managers must establish and encourage norms, roles, and rules for efficient application to known tasks, but must also be sensitive and responsive to change by employing sensitivity, problem solving, and decision making strategies that allow for adaptation (Chemers, 2001).

\section{Developing MI in the Organizations}

Whether intelligence can develop depends upon three main factors (Armstrong, 2009, p.27):

1). Biological endowment - including hereditary or genetic factors and insults or injuries to the brain before, during, and after birth

2). Personal life history - including experiences with parents, teachers, peers, friends, and others who awaken intelligences, keep them from developing, or actively repress them

3). Cultural and historical background-including the time and place in which you were born and raised and the nature and state of cultural or historical developments in different domains we can see the interaction of these factors in the life of Wolfgang Amadeus Mozart.

\section{Suggestions for Further Research of MI in the context of Organization}

1). In this study, managers' capabilities were discussed only through Gardner's MI theory. In another study, researchers can make use of other kinds of assessment tools such as observation, interviewing staff or a combination of different assessment devices to assess organizational effectiveness in organizations.

2). In terms of gender and the managers' MI, the research should be done with sufficient numbers of participants in each sex.

3). To the researchers' knowledge, this is the first attempt to explore the relationship between managers' MI and their success. Thus, this study should be replicated.

4). Since this study was conducted only at organizational effectiveness, further research is needed to be done in private institutes and SME's in order to compare the results.

5). This study can also be replicated for managers who are interested to participate in MI based learning methods.

\section{Conclusions}

As a manager who has a good Emotional Intelligence, EI and competitive intelligence can cope with the market an organizational facts well than others who do not have more so a manager who has a good MI can manage the situation and run the business more successfully than the others too.

Also managers should note that they should use their intelligences to find the effective organization model to manage the circumstances and also remember that the organizational effectiveness in modern organizations is 
much more different with the past organizations and the modern organizations are in turbulent time and all the time the organizational goals may change.

The downside of this fortunate circumstance for many organizations is that it has become increasingly more difficult to retain good employees, particularly those with the skills that are important in the high-tech economy. So what aspects of an organization are most important for keeping good employees (Cherniss, 2001)?

Also studies show that:

Highly conscientious managers who lack social and emotional intelligence perform more poorly than those high in both conscientiousness and emotional intelligence.

- On average, strengths in purely cognitive capacities are approximately $27 \%$ more frequent in high performers than in the average performers, whereas strengths in social and emotional competencies are 53\% more frequent.

- The highest performing managers and leaders have significantly more "multiple intelligences competencies" than other managers.

- Poor social and multiple intelligences are strong predictors of executive and management "derailment" and failure in a person's career.

Also CEOs for leveraging their managers should:

- Review the origins and current status of MI and social intelligence in organizations

- Explore research, best practices and future directions of MI and OE

- $\quad$ Select context appropriate MI assessment and measurement tools

- Distinguish between cognitive learning and multiple intelligences based learning strategies

- Learn to build the "business case" for MI \& evaluate the effectiveness of MI learning strategies

Also managers should do the following practical guides for their staff to enhance MI competencies: Strategic learning framework for developing emotional competence in organizations

- Introduction to MI-based action learning projects

- Overview of MI (i.e., history, definitions, theoretical basis, research highlights, the "business case" and general applications)

- Application: MI and Organizational Coaching Processes (e.g., executive coaching and peer coaching)

- Application: Connections between emotional competence, customer loyalty and competitive advantage

- The Measurement and Assessment of MI

- Evaluating the Effectiveness of MI interventions

- Application: MI, Diversity and Cultural Competence

- Application: MI and Leadership Development (i.e., integrating MI competencies in various leadership development interventions and processes such as succession planning)

- Share preliminary ideas for MI-based action learning projects

\section{References}

Anspach, R. R. (1991). Everyday Methods for Assessing Organizational Effectiveness. Social Problems, 38 (11, 1-19).

Armstrong, T. (2000). Multiple intelligences in the classroom. Alexandria, VA, USA: Association for Supervision. Retrieved July 18, 2007 [Online] Available: http://site.ebrary.com/lib/modarres/Doc?id=10044795\&page=1

Armstrong, T. (2010). Multiple intelligences in the classroom. Third Edition, Alexandria, Virginia USA,

Brown, H. D. (2000). Principles of language learning and teaching ( $4^{\text {th }}$ ed). San Francisco: Pearson Education.

Cameron Kim. (1981). The Enigma of Organizational Effectiveness.

Cameron, K. (1978). Assessing Organizational Effectiveness in Institutions of Higher Education. Administrative Science Quartrrly, 1978, 23, 604-632. 
Cameron, K. S., and Whetten, D. A. (eds.). (1983). Organizational Effectiveness: A Comparison of Multiple Models. San Diego: A cademic Press.

Campbell, L. M. (2000). The unspoken dialogue: Beliefs about intelligence, students, and instruction held by a sample of teachers familiar with the theory of multiple intelligences. Unpublished doctoral dissertation, The Fielding Institute. United States.

Cary Cherniss. (2001). EMOTIONAL INTELLIGENCE AND ORGANIZATIONAL EFFECTIVENESS. [Online] Available: http://www.mtpinnacle.com

Chastain, K. (1988). Developing second language skills: Theory and practice (3rd ed). United States of America: Harcourt Brace Jovanovich.

Chemers, Martin M. (2001). Leadership, Change, and Organizational Effectiveness. [Online] Available: http://www.almaden.ibm.com/

Cook, R. S., and Brown, N W. (1990). Most Effective and Least Effective Boards of Nonprofit Human Service Agencies. Group and Organization Studies, 15 (4), 431447.

D. Baugher. (1981). New Directions for Program Evaluation: Measuring Effectiveness. no. 11 San Francisco: Jossey-Bass, September 1981

Drucker, P. E. (1990). Managing the Nonprofit Organization. New York: HarperCollins.

Drucker, P. F. (1974). Management: Tasks, Responsibilities, Practices. New York: Harper Collins,

Gardner, H. (1993). Multiple intelligences: The theory in practice. New York: Basic Books.

Gardner, H. (1993). Multiple intelligences: The theory in practice. New York: Basic Books.

Gardner, H. (2004). A multiplicity of intelligences: In tribute to Professor Luigi Vigno. Retrieved May 2, 2007

[Online]

Available:

http://www.howardgardner.com/Papers/documents/T-101\%20A\%20Multiplicity\%20REVISED.pdf

Gardner, H. (2006a). Multiple intelligences: New horizons in theory and practice. New York: Basic Books.

Goodman, P. S., and Pennings, J. M. (1977). New Perspectives on Organizational Effectiveness. San Francisco: Jossey-Bass.

Goodman, P. S., and Pennings, J. M. (1977). New Perspectives on Organizational Effectiveness. San Francisco: Jossey-Bass.

Green, Jack C., and Donald W Griesingev. (1996). Board Performance and Organizational Effectiveness in Nonprofit Social Services Organizations. NONPROFIT MNAGEMENT \& LEADERSHIP, vol. 6, no. 4, Summer 1996

Hall, R. H. (1991). Organizations: Structures, Processes, and Outcomes. Englewood Cliffs, N.J.: Prentice Hall.

Hannan, M. T., and Freeman, J. H. (1977). Obstacles to Comparative Studies. In P. S. Goodman and J. M. Pennings (Eds.), New Perspectives in Organizational Effectiveness. San Francisco: Jossey-Bass.

Herman, R. (ed.). (1989). Nonprofit Boards of Directors: Analysis and AppZications. New Brunswick, N.J.: Transaction,

Kanter, R. M., and Brinkerhoff, D. (1981). Organizational Performance: Recent Developments in Measurement. Annual Reviews in Sociology, 7, 321-349.

Kraft, K. L. (1991). The Relative Importance of Social Responsibility in Determining Organizational Effectiveness: Managers from Two Service Industries. Journal of Business Ethics, 10,485-49 1.

Kushner, Roland J., Peter. (1996). Poole Exploring Structure-Effectiveness Relationships in Nonprofit Arts Organizations. NONPROFIMT ANAGEMEN\&T LEADERSHI, vol, 1. 7, no. 2, Winter 1996, Q Jossey-Bass Publishers, pp.119-136

Molnar, J. J., and Rogers, D. C. (1976). Organizational Effectiveness: An Empirical Comparison of the Goal and System Resource Approaches. Sociological Quarterly, 17, 401-413.

Penn, M. C. (1991). A Case Study of an Effective Board of Directors of a Nonprofit Organization: Perceptions, Processes, Characteristics, and Diversity." Unpublished doctoral dissertation, Virginia Commonwealth University. 
Powell, W. W. (ed.). (1987). The Nonprofit Sector: A Research Handbook. New Haven, Conn.: Yale University Press.

Price, J. (1972). The Study of Organizational Effectiveness. Sociological Quarterly, Z., 3-1.5

Quinn, R. E., and Rohrbaugh, J. (1983). A Spatial Model of Effectiveness Criteria: Towards a Competing Values Approach to Organizational Analysis. Management Science, 29 (3), 363-377.

Reed, J. (2007, September). Learning with IB. IB World. Retrieved June 30, 2008, [Online] Available: http://www.ibo.org/ibworld/sept07/

Richards, J. C., \& Rodgers, T. S. (2001). Approaches and Methods in Language Teaching (2 ${ }^{\text {nd }}$ ed). Cambridge: Cambridge University Press.

Sarangapani, P. M. (2000). The great Indian tradition. Retrieved June 30, 2008, [Online] Available: http:// www.india-seminar.com/2000/493/493\%20padma\%20m\%20sarangapani.htm

Sarangapani, P. M. (2000). The great Indian tradition. Retrieved June 30, 2008, [Online] Available: http:// www.india-seminar.com/2000/493/493\%20padma\%20m\%20sarangapani.htm

Seashore, S. E. (1983). A Framework for an Integrated Model of Organizational Effectiveness. In K. S. Cameron and D. A. Whetten (eds.), Organizational Effectiveness: A Comparison of Multiple Models. San Diego: Academic Press.

Spray, S. L. (ed.). (1976). Organizational Effectiveness: Theory, Research, Utilization. Kent, Ohio: Kent State University Press.

Steers, R. M. (1977). Organizational Effectiveness: A Behavioral View. Santa Monica, Calif.: Goodyear.

Steers, R. M. (1977). Organizational Effectiveness: A Behavioral View. Santa Monica, Calif.: Goodyear.

Sternberg, R. J. (1986). What is intelligence? Norwood, NJ: Ablex.

Sternberg, R. J. (1988). The triarchic mind: A new theory of human intelligence. New York: Viking.

Vygotsky, L. S. (1978). Mind in society: The development of higher psychological Processes. Cambridge, MA: Harvard University Press.

Yekovich, F. R. (1994). Current issues in research on intelligence. Educational Resources Information Center Digest \#385605

Yuchtman, E., and Seashore, S. (1967). A System Resource Approach to Organizational Effectiveness. American Sociological Review, 32, 891-903.

Table 1. Model Used to Define and Assess Organizational Effectiveness

\begin{tabular}{|c|c|c|}
\hline Model & Definition & When Useful \\
\hline & $\begin{array}{l}\text { An Organization is Effec- } \\
\text { tive to the extent that. . }\end{array}$ & \\
\hline Goal Model & $\begin{array}{l}\text { it accomplishes its stated } \\
\text { goals. }\end{array}$ & $\begin{array}{l}\text { Goals are clear, consensual, } \\
\text { measurable }\end{array}$ \\
\hline $\begin{array}{l}\text { System-Resource } \\
\text { Model }\end{array}$ & $\begin{array}{l}\text { it acquires needed } \\
\text { resources. }\end{array}$ & $\begin{array}{l}\text { Clear conncction between } \\
\text { inputs and outputs }\end{array}$ \\
\hline $\begin{array}{l}\text { Internal Process } \\
\text { Model }\end{array}$ & $\begin{array}{l}\text { it has an absence of } \\
\text { internal strain, smooth } \\
\text { internal functioning. }\end{array}$ & $\begin{array}{l}\text { Clear connection between } \\
\text { processes and primary task }\end{array}$ \\
\hline $\begin{array}{l}\text { Strategic- } \\
\text { Constituencies Model }\end{array}$ & $\begin{array}{l}\text { all strategic constitu. } \\
\text { encies are at least } \\
\text { minimally satisfied. }\end{array}$ & $\begin{array}{l}\text { Constitucncics have power- } \\
\text { ful influence; the } \\
\text { organization reacts }\end{array}$ \\
\hline
\end{tabular}

